The footnotes provide particularly insightful examinations of the links between the poetry of Gambara and that of Petrarch and Lorenzo de' Medici. They also offer an intriguing hypothesis regarding Gambara's exploration of the theological doctrine of predestination, and examine her support of the Medici rule throughout her tenure as Countess of Correggio.

Regarding the debate as to whether certain poems were penned by Gambara or Colonna, Martin and Ugolini abide by Bullock's 1995 catalogue. One notable exception is "Vinca gli sdegni e l'odio vostro antico" (May the holy and sacred name of Christ overcome your outrage and your ancient hatred), which Martin and Ugolini attribute to Gambara, citing the poem's publication history as evidence of authorship.

Poems appear first in Italian, followed by an English prose translation. This accessible format is only problematic for the Stanze, a lengthy ottava rima for which a facing translation would have made for easier reading.

In conclusion, Martin and Ugolini's bilingual edition of Gambara's complete poetic works is a much needed and highly opportune addition to early modern literary studies.

BENEDETTA LAMANNA

University of Toronto

\title{
Goodrich, Jaime.
}

Faithful Translators: Authorship, Gender, and Religion in Early Modern England.

Evanston, IL: Northwestern University Press, 2014. Pp. xi, 244. ISBN 978-08101-2938-2 (paperback) US\$39.95.

In her dynamic study of women's authorial agency in early modern England, Jaime Goodrich argues for a reevaluation of early modern translation and the possibilities it afforded for women's cultural, political, and religious engagement. Broadly, Goodrich contests the view that translation yielded fewer opportunities for expression than original authorship, especially for women, maintaining that translation instead provided "an extreme form of polyvocality" (191) that opened powerful avenues of articulation. More specifically, Goodrich focuses on women's religious translation, a body of work 
that has been largely neglected by critics despite the fact that it accounts for the majority of translations made by early modern Englishwomen. In doing so, she shows that, although early modern Englishwomen predominantly translated religious texts whose authority demanded conservative or faithful translation strategies, they were far from "passive conduits" (6) for the voices of the (usually male) authors they translated. Although Goodrich acknowledges that these female translators had to navigate an array of gender expectations imposed by the patriarchal structures of their society, she works to illuminate the important contributions that female translators made to the political and religious climate of early modern England.

One of the book's greatest strengths lies in the selection of translators and translations Goodrich considers. The seven translators who receive her primary attention are drawn from various social and religious backgrounds, while the translations were made in the early sixteenth through early seventeenth centuries and range from poetry to prose and from manuscript to print. Each of the four chapters is meticulously crafted around a different "authorial role" (25) assumed by various early modern English translators of both genders, and features case studies of two representative translations by different women. Careful attention is paid to subtle changes made to the source texts as well as to a wealth of paratextual material, and each translation is carefully placed within its cultural, political, religious, and literary contexts. While Goodrich does pay close attention to differences between men's and women's translations in early modern England, she puts each of her translators into conversation with a number of others, male and female, in order to demonstrate "that these women's translations were not anomalous but rather emblematic of specific cultural agendas" (26).

In the first chapter, Goodrich explores the ways in which female translators and their editors could collaborate in manipulating the feminine modesty topos. She illustrates how the translation activities of Margaret More Roper and Mary Roper Basset were presented as private, domestic endeavours in a deliberate bid to affect public perceptions of the More family. In this way, Roper and Basset were able to shape both their own reputations as learned women and the reputation of Roper's father and Basset's grandfather, Thomas More. Roper's translation of Erasmus's Devout Treatise upon the Pater Noster (1526) publicly established the More family's support for Erasmus, while 
Basset's translation of More's Of the Sorowe of Christ (1557) worked to bolster More's status as a martyr.

Chapter 2 examines how male editors sought to capitalize upon the names of Mary and Elizabeth Tudor by using the princesses' translations for their own propagandistic purposes. Goodrich argues that, despite these appropriative actions, Mary's translation of Erasmus's "Paraphrase [...] upon the Gospell of Sainct John" (1548) and Elizabeth's translation of Marguerite de Navarre's A Godly Medytacyon of the Christen Sowle (1548) suggest the possibility that a female translator could hold an authority equal to the author of her source text. Perhaps most interestingly, this chapter reveals Mary's covert promotion of Catholic doctrine within her translation, which was included within the English edition of the Paraphrases - a text of great importance to the Edwardian Reformation.

In the third chapter, Goodrich shows how women, like men, could use translation to present themselves as learned counsellors. She argues that close attention to Mary Sidney Herbert's presentation copy of the Psalmes (1599), intended as a gift for Elizabeth I, can be read in the context of military engagement with Spain and as guidance towards continued war against Catholicism. Following this, Goodrich asserts that Elizabeth's own translation of Boethius's The Consolation of Philosophy (1593) can be read as Elizabeth's attempt to counsel herself after the Catholic conversion of France's Henry IV.

The final chapter of the book shifts from England to the Continent, focusing on the anonymous translations of Benedictine nuns living in the Brussels and Cambrai convents. In this chapter, Goodrich contends that anonymity, rather than being strictly prohibitive, could be used by individual nuns as a tool to represent their own dissident views as commonplace within their monastic communities. Mary Percy's translation of Gagliardi and Berinzaga's The Abridgment of Christian Perfection (1612) and Potentiana Deacon's translation of François de Sales's Delicious Entertainments of the Soule (1632) indicate widespread support for Ignatian practices within their convents, although, in reality, conflict over Ignatianism was rampant. By withholding their own names and identifying themselves only as members of a larger collectivity, Percy and Deacon were able to assume a form of control over the public image of their communities.

Ultimately, Goodrich's book provides a powerful defense of the political potential inherent in translation, and she concludes by arguing for closer 
attention to heteroglossia and intertextuality in general. By revealing some of the different ways in which early modern Englishwomen used translation to comment on political and religious matters of their time, Faithful Translators suggests productive avenues of inquiry into early modern views of female authorship and the development of women's authorial agency.

KARALYN DOKURNO

University of Manitoba

\section{Middleton, Thomas.}

\section{A Trick to Catch the Old One. Ed. Paul A. Mulholland.}

The Revels Plays. Manchester: Manchester University Press, 2013. Pp. xviii, 334. ISBN 978-0-7190-1555-8 (hardback) £70.

Paul Mulholland has produced a detailed, scrupulously researched, and wellargued critical edition of one of Middleton's well-known plays. A Trick to Catch the Old One was printed in 1607 "or early in the new year" (1) and previously performed by the most famous boys' playing company, The Children of St Paul's. The persuasiveness with which Mulholland presents a large body of evidence from a complex textual history of the play makes this a groundbreaking edition of $A$ Trick, and one that will have a long shelf life. The edition will stand out among others, not only because of the wealth of evidence and the clarity with which it is presented, but also because new findings are offered convincingly, while familiar evidence is re-assessed in accordance with the latest directions in textual scholarship. Mulholland's edition is based on sixteen copies of the second quarto (Q2) and seventeen modern editions. In preparing this modernized text, the editor considered all printed copies of the play. The edition modernizes spelling and punctuation silently; when meaning is affected, variations appear in the collation. This method follows contemporary editorial practice in modern-spelling editions of other Renaissance playwrights.

The introduction delineates in painstaking detail the collation procedure, the circulation of various copies of the texts and their histories, and the relationship between this copy of the play and other play texts by Middleton's contemporaries, whose work is relevant both textually and in terms of their individual print histories. Separate parts of the introduction are devoted to the 